RETRACTION NOTE

\title{
Retraction Note to: LISPRO mitigates $\beta$-amyloid and associated pathologies in Alzheimer's mice
}

Ahsan Habib, Darrell Sawmiller, Song Li, Yang Xiang, David Rongo, Jun Tian, Huayan Hou, Jin Zeng, Adam Smith, Shengnuo Fan, Brian Giunta, Takashi Mori, Glenn Currier, Douglas Ronald Shytle and Jun Tan

(c) The Author(s) 2021

Cell Death and Disease (2021)12:1142; https://doi.org/10.1038/s41419-021-04444-7

Retraction Note to: Cell Death \& Disease https://doi.org/10.1038/ cddis.2017.279

The Editors have retracted this article because an investigation by the University of South Florida concluded that Figs. 7b, e and 8c-e present inappropriately duplicated images and that these images and the text associated with them are not scientifically defensible. Adam Smith, Brian Giunta, Glenn Currier, and Douglas Ronald Shytle agree with this retraction. Ahsan Habib, Darrell Sawmiller, and Takashi Mori disagree with this retraction. Jun Tan, Yang Xiang, David Rongo, Huayan Hou, and Song Li have not responded to any correspondence from the publisher about this retraction. The publisher was unable to contact Jun Tian, Jin Zeng, and Shengnuo Fan.

\begin{abstract}
(c) (i) Open Access This article is licensed under a Creative Commons Attribution 4.0 International License, which permits use, sharing, adaptation, distribution and reproduction in any medium or format, as long as you give appropriate credit to the original author(s) and the source, provide a link to the Creative Commons license, and indicate if changes were made. The images or other third party material in this article are included in the article's Creative Commons license, unless indicated otherwise in a credit line to the material. If material is not included in the article's Creative Commons license and your intended use is not permitted by statutory regulation or exceeds the permitted use, you will need to obtain permission directly from the copyright holder. To view a copy of this license, visit http://creativecommons. org/licenses/by/4.0/.
\end{abstract}

(c) The Author(s) 2021 